\title{
Analysis of Business Information Services Innovation in Bantaeng, South Sulawesi
}

\author{
Badu Ahmad \\ Department of Public Administration \\ Hasanuddin University, Makassar, Indonesia \\ baduahmad7@gmail.com
}

\begin{abstract}
This article aims to explain how public service innovation forms in business licenses in local government in Indonesia. For this purpose the study was conducted in Bantaeng district, South Sulawesi Province, Indonesia. The research was conducted using qualitative so that data collection techniques include observation, in-depth interview, and focus group discussion. The result of the research shows that service innovation applied in bantaeng district has the purpose of providing satisfactory business permit services for the community through various main policies such as changing employee behavior, delivery of permits to applicant's home, and utilization of information technology. Innovation made it was able to encourage the acceleration of business license services. We can conclude that there is a positive trend of regions in Indonesia in an effort to improve public services more efficiently and effectively in the second decade of democratization in the country.
\end{abstract}

Keywords: innovation; public service; business license; local government; Indonesia

\section{INTRODUCTION}

Empirically, there are several regions in Indonesia to be the best practice reference in applying innovation in public service such as; public service units of Pinrang District, Jemrana District, Sragen District, Banyuangi District, and Gorontalo for institutional innovation through capacity building and bureaucratic mindset changes to mindset entrepreneur. In line with the view of Prasojo which suggests that the districts that successfully innovate the licensing service can improve the quality of service and the satisfaction and welfare of society [1]. Therefore, organizational regulation can encourage the formation of innovations that can improve the performance of public services, respond to the expectations of citizens and community needs [2]. Furthermore Dwiyanto proposed innovation services based on information technology and communication one of the strategies to realize the accountable and transparent service as a pillar of Good Governance paradigm [3]. This is in line with the views of Ratminto and Winarsi that service by public bureaucrats is one of the manifestations of function as a public servant [4].

Despite improvements in public services carried out by the local government in South Sulawesi, there are still some shortcomings that require special attention by the regional apparatus organization (OPD) in South Sulawesi as an effort to improve the quality of public services. The condition is in line with the results of research from the author which shows the performance of public services in South Sulawesi has not been maximal so that innovation and creativity required local government [5]. According to Sinambela the importance of improving public services is one of the benchmarks for legitimacy, credibility and government capacity everywhere [6]. Similar disclosed Dwiyanto [3], that improving the performance of public service bureaucracy will also improve the level of public confidence to the government.

Based on the above description, the focus of this research is related to the analysis of the application of service innovation in Bantaeng District, Province of South Sulawesi. The author assume that innovation in the service of a good business license and satisfy the public will have an impact on the increase of revenues of Original Income of District (PAD) and welfare of society, the investment climate is increasing, and open new job opportunities and improving the welfare of the community. Thus, this research aims to analyze the form and application of innovation service business license in Bantaeng District.

\section{RESEARCH METHOD}

The location of this research in Bantaeng District, South Sulawesi Province, Indonesia. The approach used is qualitative so that data collection techniques include observation, in-depth interview, and focus group discussion. To obtain relevant and accurate data and information, the informant is the secretary of the department, the head of the licensing service, the head of the investment field, the service officer, and the business actor in charge of the business license. While data analysis techniques refer to the interactive model of Miles and Huberman [7] as follows: Data collection, data reduction, cata writing, conclusion and verification.

\section{RESULT AND DISCUSSION}

\section{A. Public Sector Innovation in Empirical Perspective}

Irwan [8] suggests the success of local governments in innovating is seen as a model in measuring the success of local governments. Furthermore, Doloreux [9] and Hartley [10] mentioned that local government innovation related to the improvement of work unit performance. Similarly Prasojo [1] suggests that the local government of Jemrana District has innovated electronic-based public services that have met the 
best practice criteria that can be a lesson for other local governments. Further Prasojo [1] argued that the main obstacle to implement innovation of public services in Indonesia is the sectoral ego of the regional apparatus organization (OPD). This is in line with the view of Thomas who propose innovation is largely determined by the commitment and capacity of local governments [11]. Furthermore, Rina also expressed the utilization of technological innovation in the form of smart card usage in service field including incremental innovation category from innovation level included in innovation sustaining innovation category [12].

\section{B. Innovation Concept in Perspective of Public Administration}

Frederickson argues that the model and system of service delivery to the public is one of the centers of attention and the value that will be maximized [13]. The study of innovations in public administration began to evolve as the paradigm shift from the formalistic New Public Administration to New Public Management (NPM) following market mechanisms and to the more democratic New Public Service [14]. According to Osborne and Gaebler [15], public sector managers are encouraged to find new ways of working and innovation to gain maximum results or privatize governance functions. In addition, the contribution of New Public Management to the study of service innovation is decisive because it is oriented professional managers who work efficiently and effectively [16].

Public sector innovation as the development of new policy designs, new operating standards, as an open solution that can be transformed by government agencies that adopt it. While Rogers [17], explains that innovation is an idea, practice, or object that is considered new by the individual one unit of other adoption. This is in line with the view of Halvorsen [18] which emphasizes novelty innovation of a product. Furthermore Rogers proposes several measures of innovation attributes: relative advantage, suitability, complexity, probability of trial, and ease of observation. Similarly Halvorsen [18] and Muluk [19] share the typology of public sector innovation such as improved service, service process innovation, administrative innovation or new policies, work system innovation, conceptual innovation, and innovation of radical changes or employee mental changes. Based on the attributes of these innovations, Halvorsen [18] suggests there are three categories of innovation: (1) Incremental innovation and radical innovation; related to the authenticity of innovation itself, (2) top-down innovation and botton-up innovation; the elements of leadership take decisions in accordance with their authority, and (3) need-led innovation and efficiency-led innovation; innovations that solve problems to improve service efficiency. In line with the views of Zeithaml and Berry that society desperately longs for quality service from every organizational unit [20].

\section{Innovation in Bantaeng}

Based on the results of the study found some form of innovation applied in the Office of Investment and One Stop Integrated Services (DPM-PTSP) Bantaeng District, among others: (1) Innovation Click; licensing of principle and location permit directly signed by regent with validity period of 6 (six) months. The innovation is a contribution of new service innovation typology and policy innovation by Halvorsen [18] applied to encourage the acceleration of infrastructure development and infrastructure facilities of the type of business being invested. After the investor obtained the principle permit from the regent, the next step is to manage the operational permits signed by the Office Head of the Investment and One-door Integrated Services of Bantaeng District. (2) Anti-pungli (extortion) services; to keep the integrity of clean and responsible licensing officers, the regents and heads of the department affirm to every implementing officer to "work with the heart". (3) Delivery of Permission Document; if two days after the signing of the business license is not picked up by the investor, the service officer shall deliver direct delivery to the investor. (4) Onestop service; the public utilizes automated services in extending permits a month before maturity. (5) Technological innovation in the form of "technopreneurship camp"; the government conducts training for entrepreneurs in utilizing technology to increase production and productivity through the application of various new technologies, especially seed business technology. (6) Maximizing One Stop Integrated Services (PTSP) in issuing all forms of licensing related to a business license has paid off. (7) Service process is more focused on improving service quality based on consistent standard operating procedures (SOP), computerized data processing, online registration, SMS Gateway, payment through Bank, cool and conducive service arrangement.

\section{CONCLUSION}

Application of innovation of online licensing service information system in this study is a very appropriate means to realize the service of prime permissibility that is easy, cheap, fast and transparent licensing service. Similarly click innovation that developed in Bantaeng District greatly assist the acceleration of principle permit service directly issued by Bantaeng Regent, while other operational permission quickly responded and processed at One Stop Integrated Service Unit signed by Head of DPMPTSP of Bantaeng District. Furthermore, the employee's mental innovation launched by the Bantaeng Regent 2014 has an impact on all service personnel holding the value of "service from the heart" as part of the integrity value of truth and belief so that there is no illegal levies in the licensing service process.

\section{ACKNOWLEDGMENT}

The author would like to thank the Kemenristek DIKTI through the PUPT Grant and LP2M Hasanuddin University for trust and funding in 2017. Thanks to Baharuddin and Adnan Nasution for his helpful and challenging comments. 


\section{REFERENCES}

[1] E. Prasojo. Peran Kepemimpinan Dalam Program Inovasi Daerah, Jembara. 2005

[2] G. Mulgan and Albury, Innovation in the Public Sector, Working Paper Version 1.9. Strategy Unit, United Kingdom Cabinet Office. 2003.

[3] A. Dwiyanto, Public Service Management; Caring, Inclusive, and Collaborative (Manajemen Pelayanan Publik: Peduli, Inklusif, dan Kolaboratif) Gajah Mada University Press, Yogyakarta. 2010

[4] Ratminto and A. S. Winarsi, Service Management: Development of Conceptual Model, Implementation of Citizens Charter and Minimum Service Standards, (Manajemen Pelayanan: Pengembangan Model Konseptual, Penerapan Citizens Charter dan Standar Pelayanan Minimal), Pustaka Pelajar, Yogyakarta. 2005.

[5] A.Badu, A. Public Service Management (Manajemen Pelayanan Umum), UT-Press, Jakarta. 2014

[6] L.P. Sinambela, L. P. 2010, Public Service Reform: Theory, Policy and Implementation (Reformasi Pelayanan Publik: Teori, Kebijakan dan Implementasi), Bumi Aksara, Jakarta. 2010

[7] M.B. Miles and A.M. Huberman, , Qualitative Data Analysis: an Expanded Sourcebook (2nd. Ed), Sage, London.1994

[8] N. Irwan, 2012, Dynamic Innovation of Local Government in Indonesia, Journal of Basic and Applied Scientific Research, www.texroad.com. 2012

[9] D. Doloreux, Regional Innovation System in Canada: A Comparative Study, Regional Studies, Vol ,38 isssue 5, 2004,pp. 481-494.
[10] J. Hartley, , Innovation in Governance and Public Services: Past and Present. CIPFA. Public Money and Management, Vol 25 No. 1, 2005, pp 27-34.

[11] H. Thomas. Review of Local Government Innovation Power In the Implementation of Decentralization in East Kalimantan Province (Tinjauan Daya Inovasi Pemerintah Daerah Dalam Pelaksanaan Desentralisasi di Provinsi Kalimatan Timur), Jurnal Burneo Administrasi Vol 6 No. 3. 2010, pp. 2161-2174.

[12] M.M. Rina. Inovasi Pelayanan Publik UPTD Terminal Purabaya Bungurasih, Surabaya. 2012

[13] H.G. Frederickson, New Paradigm New Public Administration (Paradigma Baru Administrasi Negara), LP3ES, Jakarta. 1984

[14] D. Denhardt, The New Public Service: Serving, Not Steering, M.E. Sharpe, New York. 2003

[15] D. Osborne, and Gaebler, 1993, T. Reinventing Government, Addison Wesley, Reading, Massachusetts,.1993

[16] E. Vigoda. New Public Management. In Jack Rabin (ed), Encyclopedia of Public Administration and Public Policy, Marcel Dekker, Inc, New York. 2003

[17] E.M. Rogers, Diffusion of Innovation, 5th Edition, The Free Press. New York. 2003

[18] T. Halvorsen, , On The Differences between Public and Private Sector innovation. Publin Report, Oslo. 2005

[19] K. Muluk, Knowledge Management: The Key to Successful Innovation of Local Governments (Knowledge Management: Kunci Sukses Inovasi Pemerintahan Daerah). FIA UNIBRAW, Malang. 2008

[20] P. Zeithaml and Berry. Delivering Quality Service: Balancing Customer Perception and Expectation, The Free Press, New York. 1990 